\title{
Evaluation of plastic hinges performance and the elastic stiffness factor of moment-resisting frame structures
}

\author{
Khosro Zehro ${ }^{*}$, Shahram Jkhsi ${ }^{1}$ \\ ${ }^{1}$ Faculty of Civil and Environmental Engineering, Near East University, Nicosia, Mersin10, Turkey
}

ARTICLE INFO

ARTICLE HISTORY:

Received: 25 January 2020

Revised: 27 April 2020

Accepted: 06 May 2020

Published: 28 June 2020

\section{KEYWORDS:}

Nonlinear static procedure, plastic hinge, moment-resisting frame, pushover analysis, reinforced concrete structure

\section{A B S T R A C T}

Nowadays, to analyse and determine the maximum seismic lateral displacement for reinforced concrete $(R C)$ structures, the most applicable procedure used by structural engineers is the nonlinear static (pushover) analysis. The nonlinear static procedure (NSP) is a common approach for analysing the seismic performance of construction structures. By directing this procedure, the weak points in each structural member can be examined, and it also determines whether the members are safe or need to rehabilitate. This process defines the level of performance and shear strength under seismic diffusion to construct each element of the structure. The displacement, the base shear, the plastic hinge model, and the effect of the different plan on seismic response of structures has been reported. When concentrating on the RC structures, it requires the ability to conduct lateral resistant force systems, which one of them is commonly known as moment-resisting frames (MRFs). In this paper, three models of RC structures considered for low-, medium-, and high-rise buildings were examined, and each model has been analysed for three different spans. These models have been analysed applying ETABS software by inputting and examining a wide range of structural parameters. A comprehensive study on the pushover curve, performance curve, among others have been performed. The aim of this study is to consider the effect of plastic hinges in various ranges of performance capacities to evaluate the elastic stiffness factor of structures.

\section{INTRODUCTION}

Earthquake-resistant structure systems designed based on standard seismic requirements provide the quality of life safety in a massive earthquake. However, it can have a structural loss or residual drift due to energy diffusion in specified structural members. The damage after a significant earthquake led to difficult or costly repairs (Chou et al., 2016). It is necessary to create mathematical models or physical models to determine the seismic performance of a current system and to change the component behavioural characteristics such as strength, stiffness, and deformation to better meet the desired performance criteria (Ravikumara et al., 2015).

Predicting the strength of structures to collapse under earthquake loads is also a crucial aspect of the engineering earthquake. The strength for collapse can be considered as a critical decision parameter for engineers to design new structures and analyse the seismic performance of current ones when undergoing earthquakes. Predicting a precise collapse is essential because the failure of structural mechanisms is the primary source of life and economic losses during and after an earthquake (Shafei et al., 2011).
Moment-resistant frames (MRFs) are commonly used in construction applications widely, including high seismic regions. These structures have lateral force resistance mainly by member's flexural behaviour. In designing earthquakeresistant structures, using an elastic response to a structure is neither practical nor economical (Vona \& Mastroberti, 2018). Consequently, new construction codes such as ASCE 7-10 and ACI 318-08 designed in such a way that under design-level seismic forces, all forms of seismic-force-resistant systems would be deformed in a ductile manner. However, when undergoing design-level earthquakes, structures are supposed to undergo large in-elastic cycles of deformation (Le-Trung et al., 2013). Nevertheless, to achieve the necessary performance, structural components and their joints need to be carefully designed and detailed to meet the required durability standards (i.e., ductility and energy diffusion capacity) that the codes expect (Uva et al., 2018).

Pushover analysis was the best method by the various rehabilitation instructions and codes for seismic performance evaluation of structures since it is algorithmically 
and conceptually simple. Pushover analysis enables to trace the process of yield and failure of the member and structural level and also to trace the development of the structure's overall capacity curve (Girgin \& Darilmaz, 2007). Relative to certain elements, frame elements have a cost-effective and precise approach for structure nonlinear response analysis. A conventional and traditional approach, the displacement-based method, was used to derive frame elements using computational methods based on estimated displaced component shapes (Li et al., 2012).

Pushover analysis was an effective way to evaluate the building's behaviour, underline the member cracking pattern and yield when the base shear value goes up. Such data may be used to determine structure performance and inelastic curvature positions. The main advantage of pushover analysis was to get an estimate of over-strength and to get a meaning of the structure's overall capacity to maintain inelastic deformation (Nilesh, 2015). When the conduct of RC structures under seismic loads could be highly inelastic, the global inelastic performance of RC structures will be controlled by plastic generating effects. Thus, the reliability of the pushover analysis would be determined by the capacity of the theoretical models to identify this effect (Kadid \& Boumrkik, 2008).

By creating and evaluating nine different models of RC structural frames with MRF and using a software package ETABS2016, the result of hinge deformation and their influence on frame structures considered in the nonlinear behaviour of structures. For each plastic hinge shaped with their order, the results computed, and observations discussed.

\section{METHODOLOGY}

\subsection{Labelling system applied for frames}

The following labelling system has been applied for frames. ST-N-S-L-H- $f_{c}^{\prime}-f_{y}$ coding has been applied.

where:

ST: The structure type (RC for reinforced concrete),

$\mathrm{N}$ : Number of spans,

$\mathrm{S}$ : Number of stories,

L: Span length,

$\mathrm{H}$ : Story height,

$f_{c}^{\prime}$ : Compressive strength of concrete,

$f_{y}$ : Rebar yield strength.

Also, some other labels that used in our study include:

MRF: Moment-resisting frame,

$\mathrm{K}$ : Elastic stiffness factor,

D: Displacement,

b: Width of beam and column,

h: Height of beam,

w: Depth of column.

\subsection{Details of Models}

Table 1. Two-dimensional models of RC structures with MRF

\begin{tabular}{|l|l|}
\hline Labels & Value \\
\hline $\mathbf{N}$ & 5 \\
\hline S & $4,7,10$ \\
\hline $\mathbf{M}$ & 9 \\
\hline $\mathbf{H}$ & $3.2 \mathrm{~m}$ \\
\hline $\mathbf{L}$ & $5.5 \mathrm{~m}, 6 \mathrm{~m}, 6.5 \mathrm{~m}$ \\
\hline Site class & $\mathrm{C}$ \\
\hline E & $200000 \mathrm{Mpa}$ \\
\hline G & $10356.49 \mathrm{Mpa}$ \\
\hline Wc & $24 \mathrm{kN} / \mathrm{m} 3$ \\
\hline $\boldsymbol{f}_{\boldsymbol{c}}^{\prime}$ & $28 \mathrm{Mpa}$ \\
\hline $\boldsymbol{f}_{\boldsymbol{y}}$ & $420 \mathrm{Mpa}$ \\
\hline SDL & $20 \mathrm{kN} / \mathrm{m} 2$ \\
\hline L.L & $25 \mathrm{kN} / \mathrm{m} 2$ \\
\hline Beams b $\times \mathbf{h}$ & $300 \times 500 \mathrm{~mm}$ \\
\hline $\begin{array}{l}\text { Column section sizes } \\
(\text { low and high-rise stories) } \mathbf{b} \times \mathbf{w}\end{array}$ & $400 \times 400 \mathrm{~mm}$ \\
\hline $\begin{array}{l}\text { Column section sizes } \\
(\text { mid-rise storey) b } \times \mathbf{w}\end{array}$ & $300 \times 300 \mathrm{~mm}$ \\
\hline
\end{tabular}

\subsection{Finding elastic stiffness factor and natural time pe-} riod

The equation for finding elastic stiffness factor:

$$
K=\frac{\mathrm{Vs}}{\mathrm{Ds}}
$$

where:

$K$ : Elastic stiffness factor,

Vs: First hinge formation,

Ds: Displacement at first plastic hinge formation

(Ngenge \& Wafi, 2020; Sarhan \& Raslan, 2020).

The equation for finding the natural time period:

$$
\mathrm{T}=2 \pi \sqrt{\frac{\mathrm{m}}{\mathrm{k}}}
$$

where:

T: Natural time period,

m: Gravity loads composed of dead loads and a speci-

fied portion of $25 \%$ live loads,

\section{RESEARCH OBJECTIVE}

We need to be predicting the deformation performance depending on how the capacity can control the demands in terms of achieving the goal. In other words, the structure must be able to withstand the earthquake's conditions, so the 
structure's performance is consistent with the design's objectives. A performance inspection specifies that structural and non-structural elements for force and displacement demand have not damaged above the safe limits of the performance objective.

This study aimed to analyse the reliability and relevance of displacement-based, forced-based, and plastic character components for the nonlinear static finite element analysis of RC structures. By modelling and evaluating the low, medium, and high-rise stories $\mathrm{RC}$ frame, the pattern of the hinge forming and its influence attempted to study. We tabulate the outcomes by Base shear, elastic rigidity factor, and time-period discussed for each RC structure model and observations.

\section{PERFORMED STRUCTURAL ANALY- SIS}

\subsection{Plastic hinge performance}

In structural engineering, a plastic hinge refers to the deformation of a part of the beam everywhere plastic bending occurs. Hinge means that you cannot restrain the moment. Consequently, a plastic hinge acts as a standard hinge allowing free rotation (Inel \& Ozmen, 2006). When understanding structural failure, the definition of the plastic hinge is relevant. In general, the plastic hinges shape at the other location of a beam:

1- Concentrated point load.

2- At supports.

3- At the maximum bending moment

(Choi and Kim, 2011).

\subsection{Pushover analysis}

Pushover analysis is a method that uses simple nonlinear techniques to predict seismic structural analysis to determine the relationship between force and displacement (Patil et al., 2017). The internal forces and deformations for the related output displacement analyse $d$ in the Pushover analysis. The objective displacement aims to reflect the total displacement, which can be accomplished by the structure after the seismic design (Boroujeni, 2013). Pushover evaluation is an expected theoretical approach by which the structure subjected to various monotonic lateral forces with a heightwise invariant distribution once the target has been displaced. The pushover analysis procedure needs three components, such as capacity, demand, and also performance, to be determined (Sonwane \& Ladhane, 2015).

\subsection{Performance levels of the structures}

The Pushover curve is a graphical analysis between the base shear along the vertical axis and the roof displacement on the horizontal axis (Alashker et al., 2015). A level of performance defines a state of minimizing the damage that can be deemed acceptable for a particular building and ground motion, the limiting state characterized by the structure's actual damage, the builder's life-safety risk developed by the damage, and also the structure's post-earthquake reliability (Singh, 2016). The performance point of the structure can be determined from the pushover curve at different levels. In terms of the base shear performance versus the roof displacement curve, as shown in Fig. 1, the different performance levels for a building expressed. The limit AB is elastic, the limit of immediate occupancy IO to LS is the limit of life safety, and LS to CP is the limit of prevention of collapse. When the force-displacement curve of a hinge reaches point $\mathrm{C}$, the hinge must start dropping the load. The structure is also said to be safe when all hinges are within the CP limit. If the hinges are shaped beyond the CP limit, on the opposite, the structure is seen to collapse. There are five levels of global structural reaction, depending on the amount of damage the system will experience when conducting pushover analysis (Kalibhat et al., 2014).

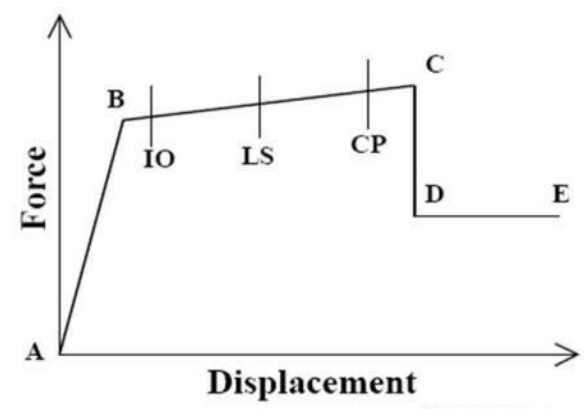

Fig. 1. Performance levels in plastic hinges (López et al., 2016)

where:

$\mathrm{IO}=$ Intermediate occupancy,

LS = Life safety,

$\mathrm{CP}=$ Collapse prevention,

Point ' $\mathrm{A}$ ' is the unloaded condition,

Point ' $\mathrm{B}$ ' is the beginning of yielding,

Point ' $\mathrm{C}$ ' is the ultimate strength,

Point ' $\mathrm{D}$ ' is the residual strength.

It suggested that non-zero residual strength beyond $\mathrm{C}$ defined for computing stability. The residual strength can be calculated to be 20 per cent of the yield strength in the absence of the simulation of the falling branch of a load versus deformation curve.

Point' E' is the optimum residual strength deformation capacity. A high value of the deformation capacity believed to preserve computational stability (Yadav et al., 2017). 


\section{RESULT AND DISCUSSION}

\subsection{Plastic Hinge formation}

In this part, some of the outcome models of plastic hinge formations shown in the figures below with the various numbers of stories. Colours for plastic hinge formation:

- is A (unloaded condition)

- is B (onset of yielding)

- is C (ultimate strength)

- is D (residual strength)

- is E (total remaining strength deformation capacity)

\subsubsection{Plastic Hinge Formation}

The results of plastic hinge formation for each number of stories with maximum span lengths shown in Fig. 2 to Fig. 4.

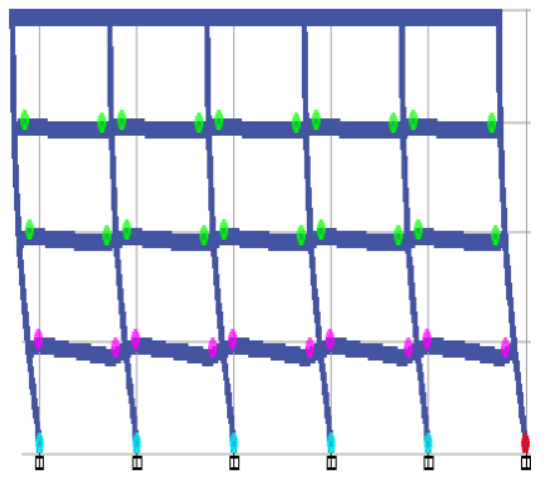

Fig. 2. Plastic hinge formation in example frame RC-5-4-6.5-28-420

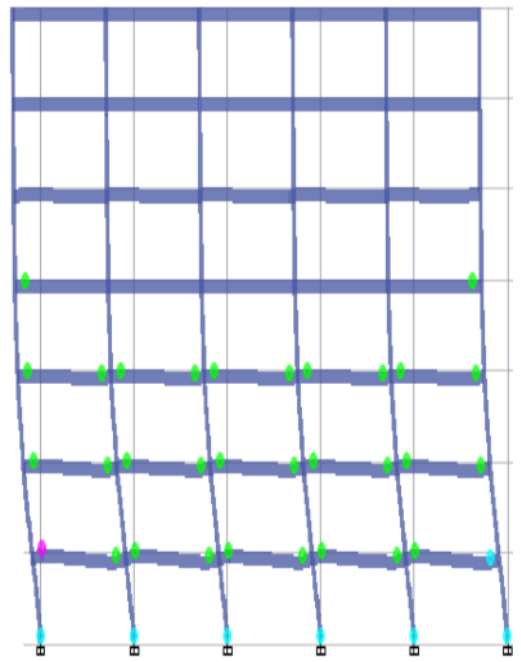

Fig. 3. Plastic hinge formation in example frame RC-5-7-6-28-420

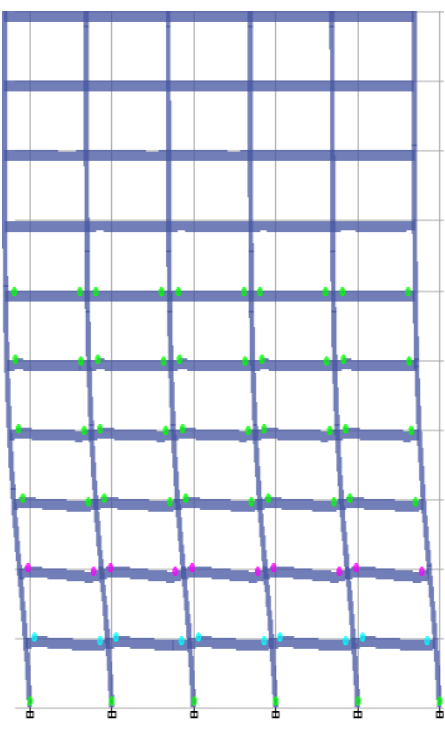

Fig. 4. Plastic hinge formation in example frame RC-5-10-6.5-28-420

\subsection{Base Shear values}

In this part, the results of different parameters affecting the maximum shear of 2D RC structural frames are shown in graphs and Tables and discussed. The base shear is the capacity of the RC frames that can withstand under lateral load; it is not the designed base shear, which used to design the frames.

\subsubsection{The effect of span length on the base shear of the RC Frames}

Span length change can affect the base shear of $\mathrm{RC}$ frames. Therefore, to evaluate that effect, the base shear of the frames versus span length change shown in Fig. 5 and Table 2. It could be seen from the graph, and Table 2 that as the span length increases, the RC frames base shear decreases.

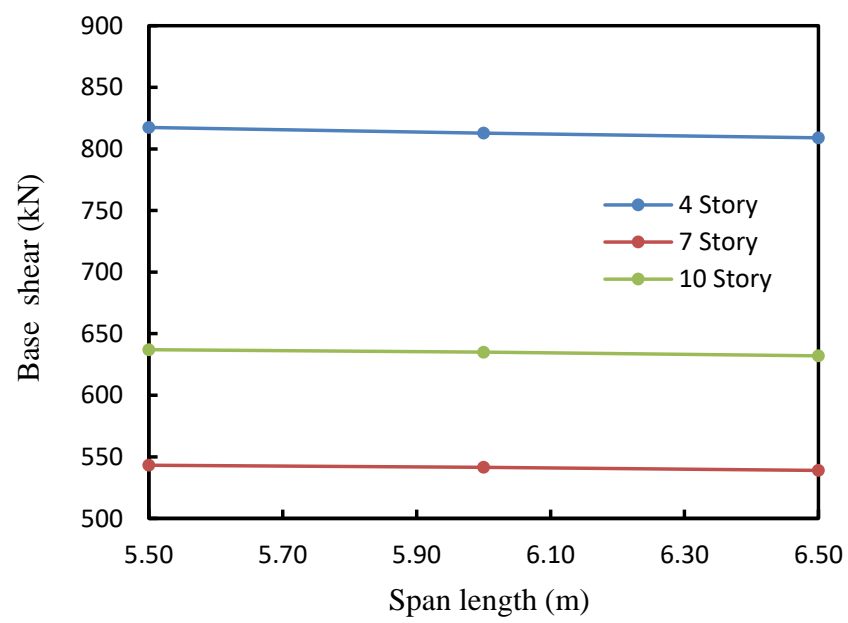

Fig. 5. Base shear versus different span length 
Table 2. Base shear for different span length

\begin{tabular}{|c|c|c|c|}
\hline \multirow{2}{*}{$\begin{array}{c}\text { Span length } \\
(\mathbf{m})\end{array}$} & \multicolumn{3}{|c|}{ Base shear (kN) } \\
\cline { 2 - 4 } & $\mathbf{4}$ & $\mathbf{7}$ & $\mathbf{1 0}$ \\
\cline { 2 - 4 } & 817.4 & 543.2 & 637 \\
\hline $\mathbf{5 . 5}$ & 812.8 & 541.5 & 635 \\
\hline $\mathbf{6}$ & 809 & 539 & 632 \\
\hline $\mathbf{6 . 5}$ & \multicolumn{3}{|c}{} \\
\hline
\end{tabular}

\subsubsection{The effect of the number of stories on the base shear of the RC frames}

The following figure and Table show the changes in the base shear of RC frames versus the number of stories. As seen in Fig. 6 and Table 3, the base shear decreased when the number of stories increases.

Table 3. Base shear for various number of stories

\begin{tabular}{|c|c|c|c|}
\hline \multirow{2}{*}{ Story no. } & \multicolumn{3}{|c|}{ Base shear $(\mathbf{k N})$} \\
\cline { 2 - 4 } & \multicolumn{3}{|c|}{ Span length } \\
\cline { 2 - 4 } & $\mathbf{5 . 5} \mathbf{~ m}$ & $\mathbf{6} \mathbf{~ m}$ & $\mathbf{6 . 5} \mathbf{~ m}$ \\
\hline L (4) & 817.4 & 812.8 & 809 \\
\hline M (7) & 543.2 & 541.5 & 539 \\
\hline H (10) & 637 & 635 & 632 \\
\hline
\end{tabular}

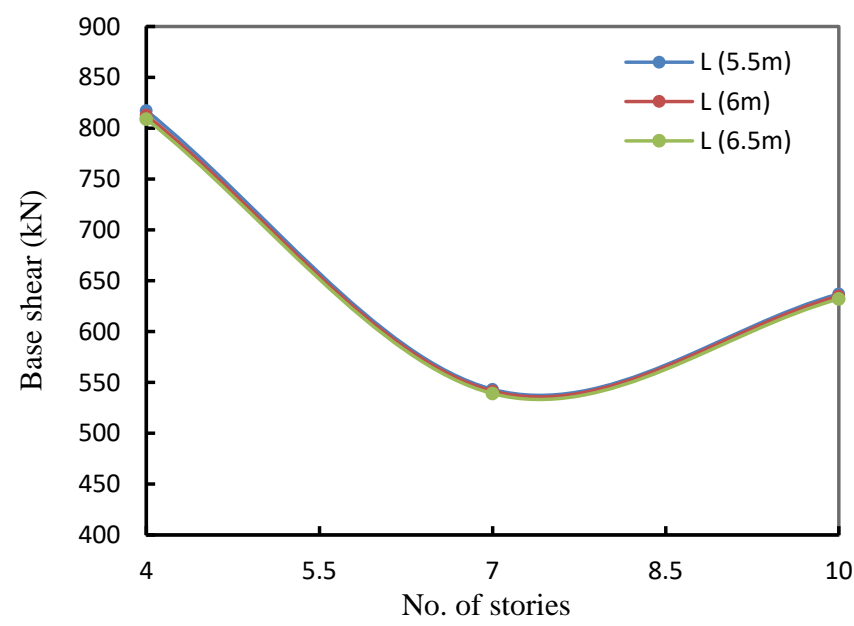

Fig. 6. Base shear versus the various number of stories

\subsection{Elastic Stiffness Factor}

The elastic stiffness of a structure affects several other parameters, and elastic stiffness is a function of some parameters described through this part. This part aims to analyse and compare the elastic stiffness of 2D RC frames by taking into account different parameters such as span length and the number of stories.

\subsubsection{Effect of span length on the elastic stiffness factor of the frames}

Changes in span length would have a significant effect on the weight and designed frame sections so that any change in span length would affect the elastic stiffness of the RC frames.

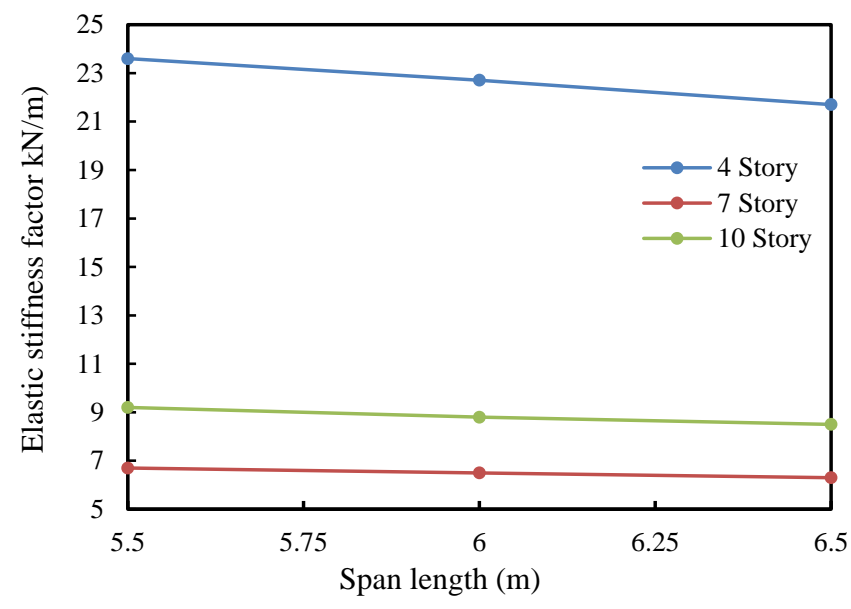

Fig. 7. Elastic stiffness factor versus different span lengths

Table 4. Elastic stiffness factor with different span length

\begin{tabular}{|c|c|c|c|}
\hline \multirow{2}{*}{ Span length (m) } & \multicolumn{3}{|c|}{ Elastic stiffness factor $(\mathbf{k N} / \mathbf{m})$} \\
\cline { 2 - 4 } & \multicolumn{3}{|c|}{ Number of stories } \\
\cline { 2 - 4 } & $\mathbf{4}$ & $\mathbf{7}$ & $\mathbf{1 0}$ \\
\hline $\mathbf{5 . 5}$ & 23.6 & 6.7 & 9.2 \\
\hline $\mathbf{6}$ & 22.71 & 6.5 & 8.8 \\
\hline $\mathbf{6 . 5}$ & 21.7 & 6.3 & 8.5 \\
\hline
\end{tabular}

Fig. 7 and Table 4 show the elastic stiffness factor of the RC frames versus span length. From the figure and Table below, it seems that with increasing span length, the elastic stiffness factor decreased in the RC frames.

\subsubsection{Effect of the number of stories on the elastic stiff- ness factor of the RC frames.}

Fig. 8 and Table 5 show the changes in the elastic stiffness factor of RC frames versus the number of stories. From the figure and Table, it is seen that the elastic stiffness factor of the frames decreased by increasing building stories.

Table 5. Elastic stiffness factor for different number of stories and different span length

\begin{tabular}{|c|c|c|c|}
\hline \multirow{3}{*}{ Story No. } & \multicolumn{3}{|c|}{ K (kN/m) } \\
\hline & \multicolumn{3}{|c|}{ Span length } \\
\hline & $5.5 \mathrm{~m}$ & $6 \mathrm{~m}$ & $6.5 \mathrm{~m}$ \\
\hline L (4) & 23.6 & 22.71 & 21.7 \\
\hline M (7) & 6.7 & 6.5 & 6.3 \\
\hline H (10) & 9.2 & 8.8 & 8.5 \\
\hline
\end{tabular}




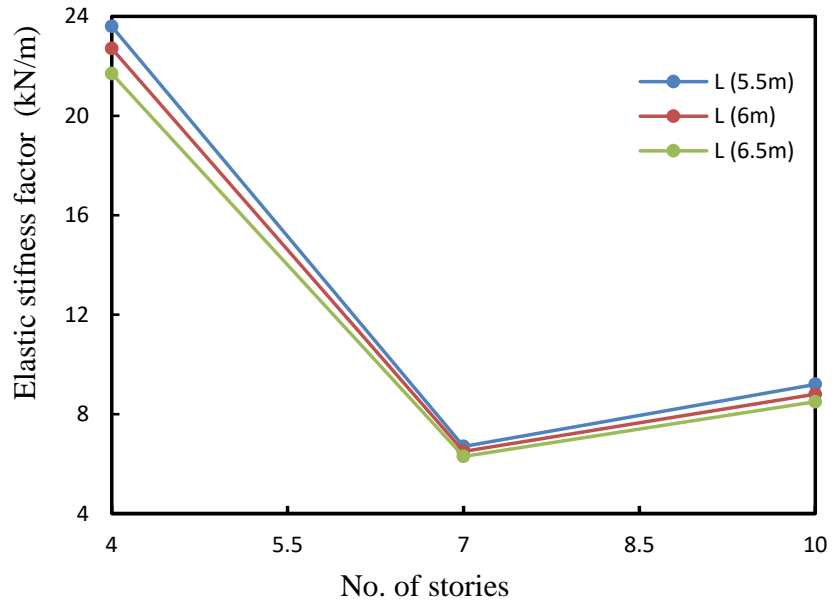

Fig. 8. Elastic stiffness factor versus the different number of stories and different span length

\subsection{Natural period}

\subsubsection{Effect of span length on the natural period}

Table 6. Natural period with different span length.

\begin{tabular}{|c|c|c|c|}
\hline \multirow{2}{*}{ Span length (m) } & \multicolumn{3}{|c|}{ Natural period (s) } \\
\cline { 2 - 4 } & \multicolumn{3}{|c|}{ Number of stories } \\
\cline { 2 - 4 } & $\mathbf{4}$ & $\mathbf{7}$ & $\mathbf{1 0}$ \\
\hline $\mathbf{5 . 5}$ & 0.75 & 1.80 & 1.92 \\
\hline $\mathbf{6}$ & 0.80 & 1.95 & 2.00 \\
\hline $\mathbf{6 . 5}$ & 0.86 & 2.10 & 2.20 \\
\hline
\end{tabular}

Fig. 9 and Table 6 show the natural time-period versus span length, and it seems that with increasing span length, the time-period increased in the RC frames.

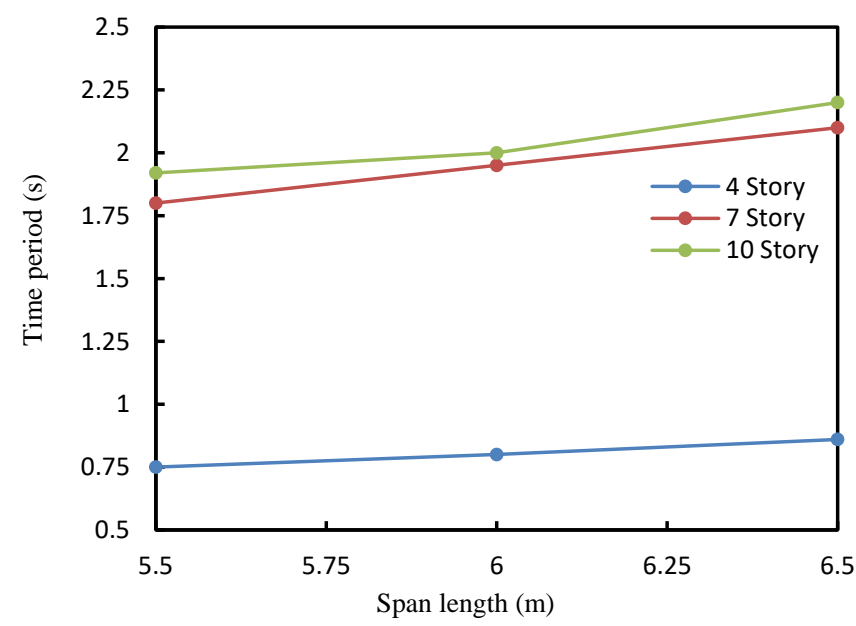

Fig. 9. Natural period versus different span length

\subsubsection{Effect of the number of stories on the natural factor}

Fig. 10 and Table 7 show the natural period versus the number of stories, and it seems that with an increasing number of stories, the natural period increased in the RC frames.

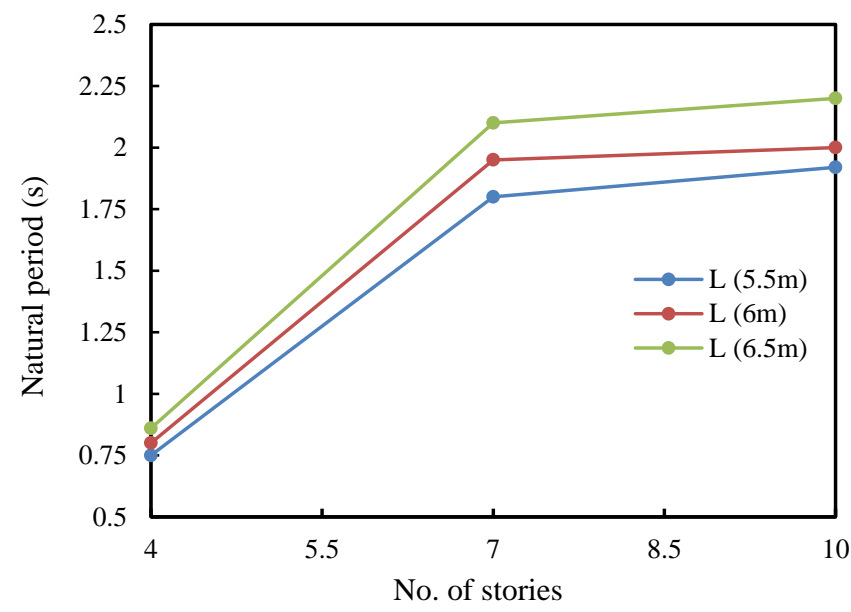

Fig. 10. Natural period versus the different number of stories and span lengths

Table 7. Natural period for different number of stories and span lengths

\begin{tabular}{|c|c|c|c|}
\hline \multirow{2}{*}{ Story No. } & \multicolumn{3}{|c|}{ Natural period (s) } \\
\cline { 2 - 4 } & \multicolumn{3}{|c|}{ Span length } \\
\cline { 2 - 4 } & $\mathbf{5 . 5} \mathbf{~ m}$ & $\mathbf{6 ~} \mathbf{~}$ & $\mathbf{6 . 5} \mathbf{~ m}$ \\
\hline L (4) & 0.75 & 0.8 & 0.86 \\
\hline M (7) & 1.8 & 1.95 & 2.1 \\
\hline H (10) & 1.92 & 2 & 2.2 \\
\hline
\end{tabular}

\subsection{Factors that affect the Pushover curve}

In this part, the consequence of various parameters on the pushover curve of RC frames is discussed.

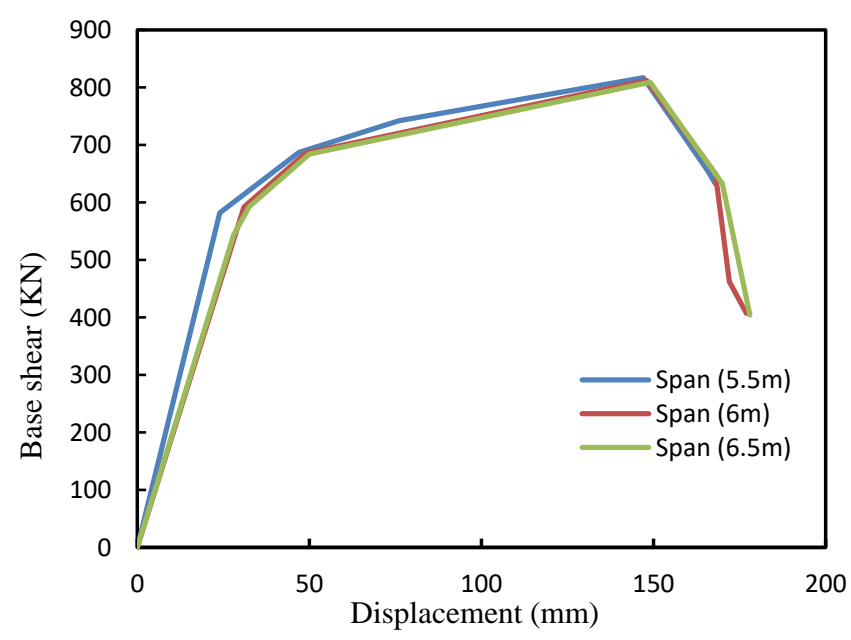

Fig. 11. Effect of span length on pushover curve (Low-rise building) 


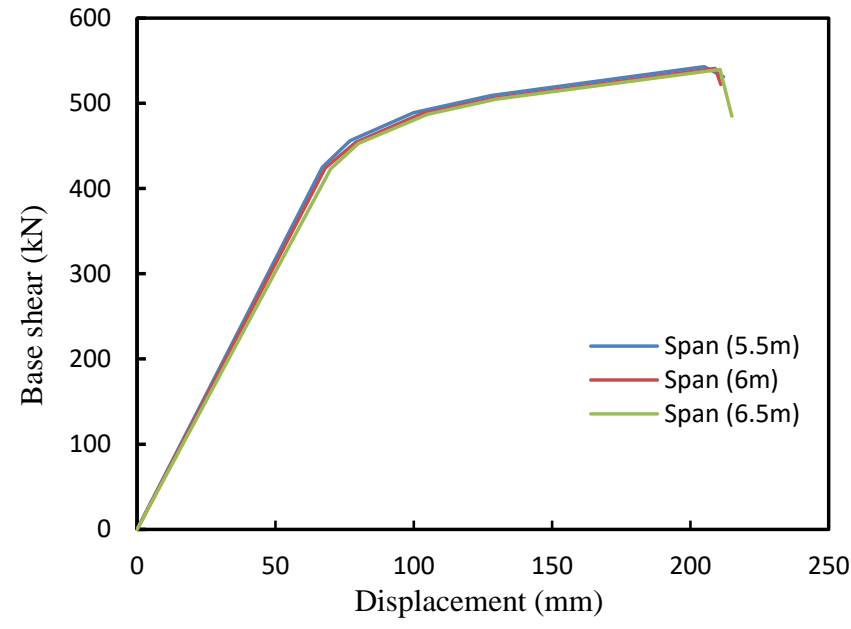

Fig. 12. Effect of span length on pushover curve (Mid-rise building)

Effects of changing span length on the pushover curve of $\mathrm{RC}$ frames are shown in Fig. 11, 12 and 13, as it is clear in diagrams by increasing the span length from $5.5 \mathrm{~m}$ to 6 $\mathrm{m}$ and then to $6.5 \mathrm{~m}$, the displacement of $\mathrm{RC}$ frames increased as well for each story building models.

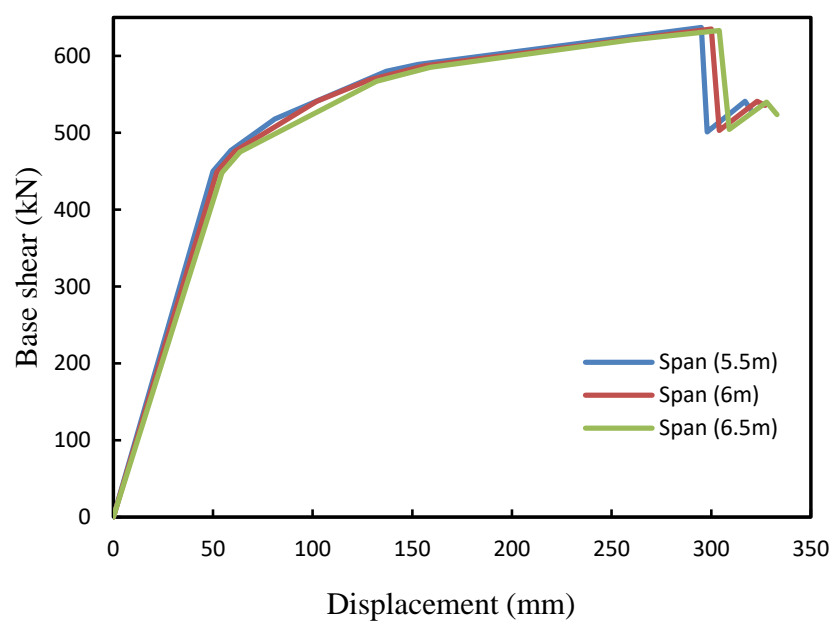

Fig. 13. Effect of span length on pushover curve (High-rise building)

\section{CONCLUSIONS}

The outcomes for all models were evaluated by inputting various span lengths and a different number of stories using the pushover analysis method. Depending on the system of pushover analysis in this study, the outcomes are in graphs and Tables showing how changing span length and the number of stories affect total base shear, elastic stiffness factor, time period, pushover curves of a structure.

By decreasing the section of columns in mid-rise (7-storey) building, the maximum shear, the Elastic stiffness factor is decreased much more.
The position of plastic hinges may change depending on the section properties of structural elements, and the location of plastic hinges may vary according to changing span lengths and number of stories. The composition of plastic hinges manages the structural deformation properties, and the performance of structures under lateral loads could be understood better if the hinge composition and displacement properties are observed.

As the span length increases, the RC frames base shear decreases, and also the base shear is decreased by increasing the number of stories. With increasing span length, the elastic stiffness factor decreased in the RC frames, and also, the elastic stiffness factor of the frames decreased by increasing in building stories.

With increasing span length, the time-period increased in the RC frames, and by increasing the number of stories, the time-period increased in the RC frames.

Also, by increasing the span length from $5.5 \mathrm{~m}$ to $6 \mathrm{~m}$ and then to $6.5 \mathrm{~m}$ in different stories, the displacement of $\mathrm{RC}$ frames increased as well.

\section{REFERENCES}

[1 ] Alashker, Y., Nazar, S., \& Ismaiel, M. (2015). Effects of Building Configuration on Seismic Performance of RC Buildings by Pushover Analysis. Open Journal of Civil Engineering, 5(2), 203-213.

[2 ] Boroujeni, A. R. K. (2013). Evaluation of various methods in FEMA356 compares to FEMA440. Journal of Civil Engineering and Construction Technology, 4(2), 51-55.

[3 ] Choi, H., \& Kim, J. (2011). The progressive collapseresisting capacity of the RC beam-column sub-assemblage. Magazine of concrete research, 63(4), 297-310.

[4 ] Chou, C. C., Tsai, W. J., \& Chung, P. T. (2016). Development and validation tests of a dual-core self-centering sandwiched buckling-restrained brace (SC-SBRB) for seismic resistance. ScienceDirect, 121(15), 30-41.

[5 ] Girgin, K., \& Darilmaz, K. (2007). Seismic response of infilled framed buildings using pushover analysis, ARI the Bulletin of the Istanbul Technical University, 54(5), 1-6.

[6 ] Inel, M., \& Ozmen, H. B. (2006). Effects of plastic hinge properties in nonlinear analysis of reinforced concrete buildings. Science Direct, 28(11), 1494-1502.

[7 ] Kadid, A., \& Boumrkik, A. (2008). Pushover analysis of reinforced concrete frame structures. Asian Journal of Civil Engineering, 9(1), 75-83.

[8 ] Kalibhat, M. G., Kumar, A. Y., Kamath, K., Prasad, S. K., \& Shetty, S. (2014). Seismic performance of RC frames with vertical stiffness irregularity from pushover analysis. IOSR Journal of Mechanical and Civil Engineering, 61-66. 
[9 ] Kashid, N. M. (2015). Performance-based seismic analysis for buildings in India, Pune, Maharashtra, India.

[10 ] Le-Trung, K., Lee, K., Shin, M., \& Lee, J. (2013). Seismic performance evaluation of RC beam-column connections in individual and intermediate moment frames. Journal of Earthquake Engineering, 17(2), 187-208.

[11 ] Li, S., Zhai, C. H., \& Xie, L. L. (2012). Evaluation of displacement-based, force-based, and plastic hinge elements for structural non-linear static analysis. SAGE Journal, 15(3), 477- 488.

[12 ] López-López, A., Tomas, A., \& Sánchez-Olivares, G. (2016). Influence of adjusted models of plastic hinges in nonlinear behavior of reinforced concrete buildings. Science Direct, 124, 245-257.

[13 ] Ngenge, J. P. L., \& Wafi, A. M. S. (2020). Assessment of plastic hinge in RC structures with and without shear walls applying pushover analysis. International Journal of Advanced Engineering, Sciences and Applications, 1(1), 11-18. Retrieved from https://www.londontechpress.co.uk/index.php/ijaesa/article/view/27

[14 ] Patil, S. S., Shah, C. R., Patil, R. A., \& Bedege, S. D. (2017). Pushover Analysis of Multi-Storey Building. International Journal of the modern trend in engineering and science, 4(3), 47-50.

[15 ] Ravikumara, H. S., Kulkarni, S. R., \& KS, B. N. A. (2015). Study of plastic hinge formation in R.C frames with non-linear static analysis. An International Journal of Research in Engineering and Technology, 4(9), 179-182.

[16 ] Shafei, B., Zareian, F., \& Lignos, D. G. (2011). A simplified method for collapse capacity assessment of moment-resisting frame and shear wall structural systems. Science Direct, 33(4), 1107-1116.

[17 ] Sarhan, O., \& Raslan, M. (2020). Study of the elastic stiffness factor of steel structures with different lateral load resisting systems. International Journal of Advanced Engineering, Sciences and Applications, 1(2), 6-11. Retrieved from https://www.londontechpress.co.uk/index.php/ijaesa/article/view/26

[18 ] Singh, R. (2016). Pushover Analysis of Multi-Storey Building (Doctoral dissertation).

[19 ] Sonwane, D. P., \& Ladhane, D. K. B. (2015). Seismic Performance-based Design of Reinforced Concrete Buildings by Nonlinear Pushover Analysis. International Journal of Innovative Research in science, Engineering and Technology, 4(06), 2278-0181.

[20 ] Uva, G., Porco, F., Fiore, A., \& Ruggieri, S. (2018, February). Effects in Conventional Nonlinear Static Analysis: Evaluation of Control Node Position. Science Direct, 13, 178-192.
[21 ] Vona, M., \& Mastroberti, M. (2018). Estimation of the behavior factor of existing RC-MRF buildings. Springer Link, 17(1), 191-204.

[22 ] Yadav, R., Gupta, T., \& Sharma, R. K. (2017). Performance Levels of RC Structures with Non-Linear Pushover Analysis. Journal of engineering research and application, 7(4), 1-8. 